\title{
Benthic communities on hard substrates covered by Limnoperna fortunei Dunker (Bivalvia, Mytilidae) at an estuarine beach (Río de la Plata, Argentina)
}

\author{
Fernando G. SPACCESI* and Alberto RODRIGUES CAPÍTULO \\ Laboratorio de Bentos, Instituto de Limnología “Dr. Raúl A. Ringuelet”, (ILPLA) CCT-CONICET-UNLP, Av. Calchaquí, km 23.5 \\ CC 712, CP 1900, La Plata, Buenos Aires, Argentina \\ *Corresponding author: spaccesi@ilpla.edu.ar
}

\begin{abstract}
The structure and composition of benthic communities on hard substrates covered by the nonindigenous bivalve Limnoperna fortunei Dunker, the golden mussel, were quantified in the middle zone of the Rio de la Plata Estuary (Argentina) from April 2001 through March 2002. A total of 26 taxa were recorded. L. fortunei and Nematoda were the central and dominant groups, with a prodigious abundance of over $80 \%$. The prevalence of $\mathrm{L}$. fortunei, rather than the environmental variables, regulated the dynamics of the associated invertebrate fauna. The golden mussel alters both the structure and function of benthic native communities on hard substrates, allows a higher surface available for colonization and refuge, and provides food source to deposit-feeding organisms in the form of organic or residual material. The mussel also increases the abundance and diversity of taxa on hard substrata - such as Oligochaeta, Hirudinea, Tardigrada, Chironomidae, Copepoda, Tanaidacea, and Hydrachnidia. Similarities and nonparametric multidimensional-scaling analyses indicated that the benthic composition had a seasonal variation. L. fortunei has an environmental impact, an ability to invade new freshwater ambiences worldwide and ecological characteristic comparable to those of Dreissena polymorpha Pallas (the zebra mussel) of North America and Europe.
\end{abstract}

Key words: alien species, biodiversity, Neotropical Region, structure and composition, temporal variation.

Received: June 2011. Accepted: November 2011.

\section{INTRODUCTION}

The environment of an estuary is characterized by a constant mixture of salt and freshwater, and dominated by sedimentary material carried from both the open sea and the associated tributaries. This transitional ecosystem has an unpredictable variation in the hydrological, morphological and chemical conditions; thus making the adaptability of animals to such a changing environment difficult (McLusky, and Elliot 2004). Differences in the composition of benthic invertebrate communities along estuarine spatial gradients are related to changes in the salinity, the content of organic material, the depth, the sediment-grain size, and the nature of the substrate (Day et al. 1989; Attrill, and Rundle 2002). In most estuaries of the world, the stress of these variable natural characteristics is intensified by human intervention - e.g., land reclamation; dredging; shipping; and waste drainage from domestic, industrial, and agricultural activities (Kiddon et al. 2003). In addition to the existing physical-chemical conditions, other influences - such as competition and the food supply - also contribute to the occurrence, distribution, and abundance of the animals inhabiting estuaries. In general, estuaries are considered areas with a high abundance of individuals with a low diversity, compared to marine or freshwater ecosystems. Several models have been developed to describe the spatial distribution and abundance of benthic species throughout estuaries (Atrill et al. 1996; McLusky, and Elliot 2004).

The Río de la Plata is a wide and shallow coastalplain estuary on the western South Atlantic between Argentina and Uruguay ( $35^{\circ} 23^{\prime}$ 'S, $56^{\circ} 23^{\prime}$ W; Fig. 1). A salient feature of this estuary is its geographical extensiveness at a length of $323 \mathrm{~km}$ and width of $230 \mathrm{~km}$ at its mouth. The Río de la Plata receives a combined average annual discharge of $22,000 \mathrm{~m}^{3} \mathrm{~s}^{-1}$ from two major tributaries, the Paraná and Uruguay rivers-one comparable to that of the Mississippi River in the USA. A turbidity front and a salt-wedge regime characterize the estuary's lower zone; where the river's freshwater flows to the sea on the surface, while the denser water runs in a countercurrent along the bottom from the platform (Guerrero et al. 1997; Mianzan et al. 2001). The shoreline is dominated by beaches composed of sand, mud, or clay, while the rocky habitat (natural or artificial) occupies a very narrow and discontinuous under-water margin. Benthic ecological studies are difficult, scarce, and fragmented because of the extensive physical dimensions of such a system, and as a result of limited financial resource as well. Nevertheless, some studies have been carried out on the seasonal dynamics and spatial-distribution patterns of the macroinvertebrate fauna along both banks of the estuary as well as within the surf zone (Boschi 1988; Rodrigues Capítulo et al. 2003; Giberto et al. 2004; Venturini 


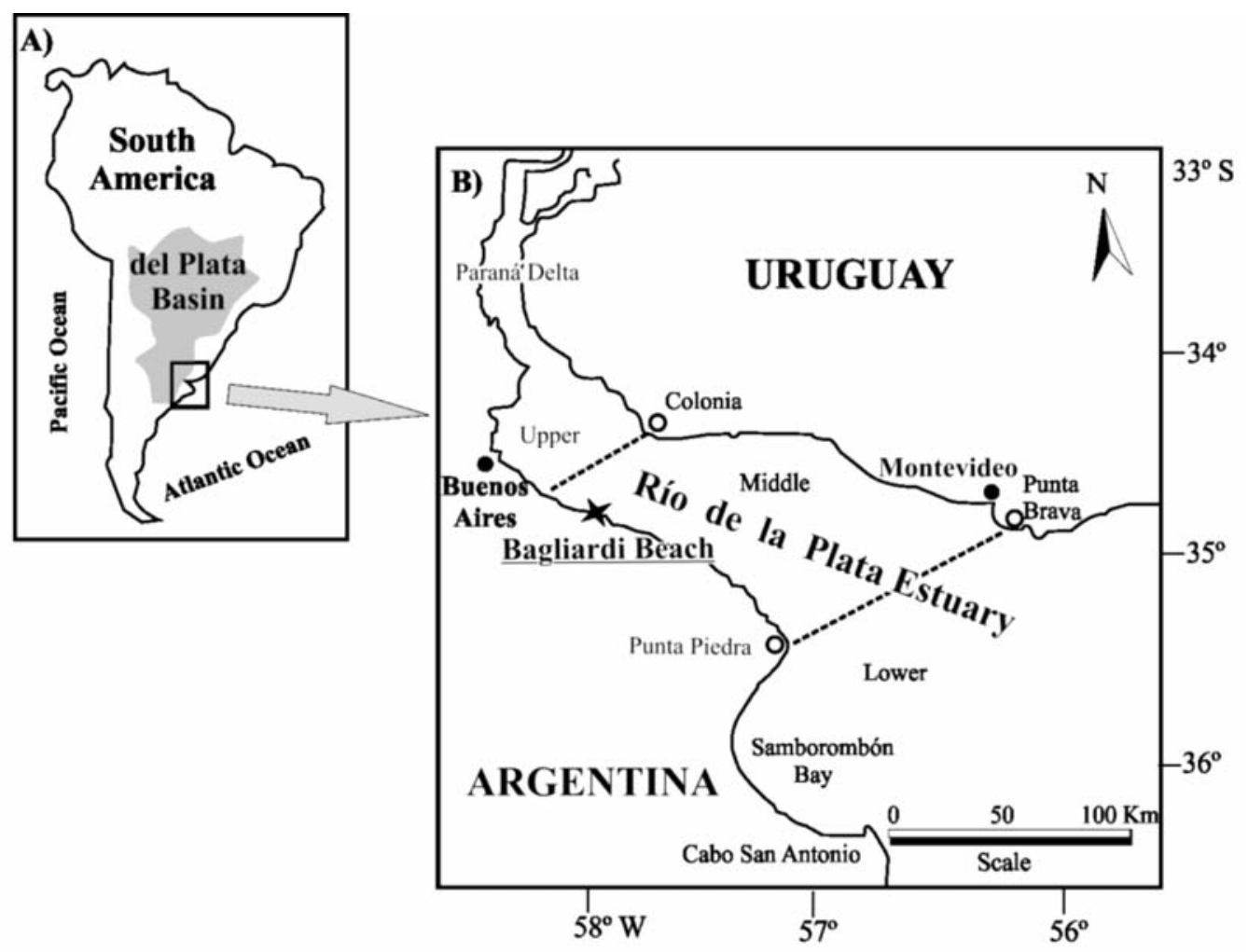

Fig. 1. A) del Plata Basin in South America B) Río de la Plata Estuary: the three main estuarine zones and the sampling site, Bagliardi Beach (Argentina).

et al. 2004; Giménez et al. 2005; Cortelezzi et al. 2007; Ocón et al. 2008). Studies, however, on the hard littoral substrates of the benthos (i.e., especially those on the benthic epifauna) in the Río de la Plata Estuary have been notably scarce (e.g., Darrigran et al. 1998).

The hard substrates of this estuary are usually occupied by the golden mussel Limnoperna fortunei Dunker (Bivalvia, Mytilidae), a nonindigenous species. This mytilid was inadvertently introduced into South America from rivers and streams in Southeast Asia through the ballast water of commercial ships. The first record of the species in the estuary was in 1991 (Darrigran, and Pastorino 1995). This freshwater mussel has subsequently spread throughout the del Plata Basin - it constituting the second most prevalent fluvial-marine system in the Neotropical Region. In the Basin before the introduction of this species no freshwater mytilid was present (Boltovskoy et al. 2006). The L. fortunei individuals form conglomerates, enabling invertebrates to associate with the byssal threads so as to provide a new shelter along with food for the benthic community (Boltovskoy et al. 2006; Sardiña et al. 2008). The benthic fauna, for their part play a significant role as one of the primary consumers within the estuarine food web.

The objectives of this work were thus to: a) analyze the temporal changes in the composition and structure of the hard-substrate-associated benthic community along the shores of the Río de la Plata Estuary (middle zone), b) describe the associated invertebrates in relation to the functional feeding groups (FFGs), and c) identify the environmental conditions that potentially may influence the occurrence and abundance of aquatic fauna on such hard substrates.

\section{MATERIALS AND METHODS}

Study site

This study was conducted (Fig. 1) in the middle zone of the Río de la Plata Estuary (Argentina), at Bagliardi Beach (34 $55^{\prime}$ S, 57²9' W). The sampling site is easily accessible and is furthermore the place where L. fortunei was discovered for the first time in South America in 1991 (Darrigran, and Pastorino 1995). There changes occurring in the populations of benthic animals living on hard-substrate habitats can be readily measured. The Río de la Plata is a temperate estuary with a salinity gradient from 0.2 PSU in the upper zone to 25 PSU in the lower zone, with the Bagliardi Beach being located in the salinity range of 0.3 PSU (Licursi et al. 2010). This estuary has semidiurnal tides with a low tidal amplitude of between 0.3 to 1 m (Bazán, and Arraga 1993; Wells, and Daborn 1997). The Bagliardi Beach contains soft sand and silt, while the hard substrates consist in compact granite rocks that are scarce and stacked inside the shoreline. 
These rocks have irregular surfaces but similar inclinations and sizes $\left(\mathrm{ca} 18,000 \mathrm{~cm}^{3}\right)$ and are relatively stable, being mostly used as shoreline defense placed by the authorities to prevent flooding under extraordinary tidal and wind conditions. This form of substrate lies within in the first $10 \mathrm{~m}$ of the littoral plain and is thus exposed both to air at low tide and to wave action at high tide. Not aquatic plants appear either among or above these rocks. At Bagliardi Beach, the mean low-water line is $0.52 \mathrm{~m}$, the mean range of tide level is $0.52 \mathrm{~m}$, and the mean level is $0.79 \mathrm{~m}$ (SHN 2001). The underwater portion of the littoral here does not follow the classical zonation because of the extremely low slope: since between 50-150 $\mathrm{m}$ of the riverside becomes exposed during the low tides, no clear vertical distribution of the benthic community occurs, as is commonly found marine ecosystems (Stephenson, and Stephenson 1949).

\section{Sampling design and data collection}

From April 2001 to March 2002 monthly samples were taken from the hard littoral underwater substrates (granite rock) that were entirely covered by $L$. fortune $i$ at Bagliardi Beach. The sampling was done on the rocks available at daytime low tides (spring tides) between the mean level and the mean low-water line on 13 April, 25 May, 23 June, 27 July, 21 August, 30 September, 25 October, 23 November, and 25 December 2001; then on 21 January, 28 February, and 31 March 2002. Five random samples were taken, each one bounded by an open $5 \times 5 \mathrm{~cm}$ wooden square according to the minimal-area criterion (Matteucci, and Colma 1982): In order to investigate this criterion for these habitats, we performed a preliminary survey in order to calculate the minimum possible sampling area using a $15 \times 15 \mathrm{~cm}$ square composed of 9 of $5 \times 5 \mathrm{~cm}$ quadrants and determined the taxa composition of each quadrant. The curve obtained by plotting the taxa per area showed a mean, minimum, and a maximum number of taxa for each sample area. We concluded that a sample area of $25 \mathrm{~cm}^{2}$ was a representative sampling for this study since that area contained an average of $80 \%$ of the total number of taxa present within an area of 225 $\mathrm{cm}^{2}$. We thus found that the benthic-taxa pattern was represented with the same probability of occurrence in the sampling unit and in all parts of the study site. The $5 \times 5 \mathrm{~cm}$ squares were placed at $c a 3 \mathrm{~m}$ from each other within a rocky platform of area $c a 81 \mathrm{~m}^{2}$. All mussels and associated fauna were removed from each square with a spatula. The samples were placed in individual plastic bags, labelled, and taken to the laboratory for processing.

The following water-quality variables were measured in situ with portable meters: the temperature $(\mathrm{T})$ in ${ }^{\circ} \mathrm{C}$ (digital thermometer), the dissolved oxygen (DO) concentration in $\mathrm{mg} \mathrm{L}^{-1}$ (Crison Oxi 330), the oxygen saturation (OS) in \% (Crison Oxi 330), $\mathrm{pH}$ (Hanna), the total dissolved solids (TDS) in $\mathrm{mg} \mathrm{L}^{-1}$ (Corning), and the conductivity (Cond) in $\mu \mathrm{S} \mathrm{cm}^{-1}$ (Corning).

\section{Laboratorial processing}

The macrobenthos and meiobenthos were sorted and rinsed with running water through a series of sieves $(500$ $\mu \mathrm{m}, 250 \mu \mathrm{m}$, and $60 \mu \mathrm{m}$ ). Individuals $>1 \mathrm{~mm}$ in length of $L$. fortune $i$ were removed from the rest of the sediment particle with forceps or by hand and were counted. The remainder of the sample - the sediments and associated benthic invertebrates - was dyed with erythrosine B and fixed with $3 \%(\mathrm{v} / \mathrm{v})$ formaldehyde. All samples were observed under a stereomicroscope $48 \mathrm{~h}$ later. Benthic organisms were identified down to different taxonomic levels according to Lopretto, and Tell (1995), Merritt, and Cummins (1996), César et al. (2000), and Fernández, and Dominguez (2001).

\section{Data analyses}

Five samples were averaged for each month and during 12 months (thus 60 samples all told were analyzed), and a biological matrix was made. The following ecological variables were used to describe the structure and composition of the benthic invertebrates on these hard substrates: the density $(N)$ in ind. $\mathrm{m}^{-2}$; the frequency $(\mathrm{Fr})$ in $\%$ of occurrence and classified according to the following criteria: constant (83-100\%: i.e., present 10-12 months of the year), common (58-75\%: i.e., present 7-9 months), rare (33-50\%: i.e., present 4-6 months); and very rare (8$25 \%$ : i.e., present $1-3$ months); the dominance $(D)$ in \%, $D=(n / N) \times 100$, where $n$ is the total number of individuals per taxon and $\mathrm{N}$ the total number of individuals of all taxa sampled; the taxa richness $(S)$; the Shannon-Wiener diversity index $\left(H^{\prime}\right)$ with data expressed as $\log 2$; and the equitability index ( $J^{\prime}$; Moreno 2001). This analysis was performed through the use of the software package PRIMER 5.2.9 (Clarke, and Warwick 2001).

The non-parametric multidimensional-scaling (nMDS) and similarities (ANOSIM) analyses were used to examine the temporal patterns and the abundance of the benthic communities according to seasonal factor: autumn (April, May, and June 2001), winter (July, August, and September 2001), spring (October, November, and December 2001), and summer (January, February, and March 2002). A similarity matrix was constructed to perform these analyses, after square-root transformation $(\sqrt{ })$ of the data, along with the Bray-Curtis coefficient used as the measure of similarity. The nMDS was used as the ordination method. The quality of nMDS fit is expressed as a stress value $(S)$, where low stress factor $(<0.2)$ corresponds to a good ordination with no real prospect of a misleading interpretation. A one-way ANOSIM was performed. The level of significance was calculated by means 999 permutations between groups. ANOSIM produces an $R$ statistic, which parameter is an absolute measure of the distance between the established groups for the parameter under consideration. $R$ values similar to 0 denote a small difference among groups, while $R$ 
values close to 1 indicate that the groups differ in community composition.

The Spearman's rank correlation was performed to test the relationships between the biological data and physical-chemical variables through the use of the Statistica 6.0 software (StatSoft Inc. 2001). The Bonferroni technique was used to determine the proper of level of significance. This analysis allowed a reduction of the likelihood of a significant correlation through chance and an over-interpretation of the data (Rice 1989). Since, however, a single environmental variable would not be expected to provide the best explanation of the biological patterns, the BIOENV procedure was applied. BIO-ENV is comparable to a multiple-regression analysis and combines and selects the environmental variables that may best explain the community-development pattern. The analysis used the Spearman correlation and Bray-Curtis coefficient as the measure of similarity. The physical-chemical variables used in the analysis were: $\mathrm{pH}$, temperature, conductivity, oxygen saturation, and dissolved-oxygen concentration. The conductivity is directly proportional to the total amount of dissolved solids in the water. Therefore, we used conductivity variable in the correlation analysis since that variable indicates the same pattern. Physical-chemical variables were transformed (except for $\mathrm{pH}$ ) to $\log _{10}(\mathrm{x}+1)$ values. The multivariate techniques (ANOSIM, nMDS, and BIO-ENV) were performed by means of the software package PRIMER 5.2.9 (Clarke, and Warwick 2001).

Functional-Feeding Groups (FFGs)

Benthic invertebrates were assigned to FFGs, according to Cummins, and Klug (1979), Cummins, and Wilzbach (1985), Bonetto, and Wais (1995), and Merritt, and Cummins (1996) in order to determine what type of feeding were being performed. Four categories of FFGs were defined in terms in percentages of abundance (\%). Group 1 (G1): the deposit-feeders and detritivores, organisms that prefer coarse particulate organic matter $(>1 \mathrm{~mm})$ and convert it to fine particulate organic matter $(<1 \mathrm{~mm})$; Group 2 (G2): the filtering and gathering collectors, individuals consuming small detritus particles $(<1 \mathrm{~mm})$ or filtered water retaining small suspended particles; Group 3 (G3): the scrapers, those being invertebrates with adaptations for grazing food on rock surfaces such as dead organic matter, seaweed, and bacteria; and Group 4 (G4): predators, organisms capturing live prey.

\section{RESULTS}

Environmental variables

The water temperature varied seasonally between $10.7^{\circ} \mathrm{C}$ in July 2001 and $27.9^{\circ} \mathrm{C}$ in December 2001. The conductivity averaged $605 \pm 344 \mu \mathrm{S} \mathrm{cm}^{-1}$. The total dissolved solids were between $203 \mathrm{mg} \mathrm{L}^{-1}$ in August 2001 and $339 \mathrm{mg}$
$\mathrm{L}^{-1}$ in April 2001. The highest value of dissolved oxygen was registered in July 2001 at $8.17 \mathrm{mg} \mathrm{L}^{-1}$ and the lowest in January 2002 at $2.6 \mathrm{mg} \mathrm{L}^{-1}$. The percentage of oxygen saturation averaged $59.15 \pm 16.66 \%$. The $\mathrm{pH}$ registered was almost neutral and remained constant throughout all the months at an averaged of $7.77 \pm 0.39$ (Tab. 1).

Univariate analyses

A total of 26 taxa were identified on the hard substrates at Bagliardi Beach (Tab. 2). Brachionus sp., Nematoda, Helobdella spp., Tubificinae, Heleobia piscium d'Orbigny, L. fortunei, Dactylobiotus dispar Murray, Hydrachnidia, and larvae of Chironomidae were found as constant groups. Naidinae, Uncanylus concentricus d'Orbigny, Cletocamptus deitersi Richard, and Cyclopoidae were common taxa. Centropagidae, Chydoridae, and Sinelobus standfordi Richardson were rare groups. Bosmina spp., Moina spp., Cyprididae, Corophium rioplatense Giambiagi, Hyalella curvispina Shoemaker, Sminthurides sp., Ceratophysella sp., Caenis sp., and larvae of Ceratopogonidae and Dolichopodidae were identified as very rare taxa.

The highest benthic-faunal density on the hard substrates was recorded in February $\left(\mathrm{N}>850,000\right.$ ind $\left.\mathrm{m}^{-2}\right)$ and the lowest in September $\left(\mathrm{N}<188,000\right.$ ind $\left.\mathrm{m}^{-2}\right)$. The highest dominance in abundance was for $L$. fortunei $(45.2 \pm 26.02 \%)$ and the Nematoda (39.73 $\pm 23.7 \%$ ) in every month, followed by the Oligochaeta, which class was present at a considerably lower percentage of dominance $(6.41 \pm 6.36 \%)$. The abundances of the other faunal groups fell markedly below all of these values (Tab. 2).

The taxa richness became the highest in July, November, and December $2001(S=16)$ and the lowest in February 2001 $(S=11)$. The equitability index showed the highest peak in September $2001\left(J^{\prime}=0.65\right)$, coinciding with the highest value of the Shannon-Wiener diversity index $\left(H^{\prime}=1.68\right)$. The lowest uniformity of fauna occurred in June $2001\left(J^{\prime}=0.2\right)$, linking at that time with the lowest diversity in the community $\left(H^{\prime}=0.49 ;\right.$ Tab. 2$)$.

\section{Multivariate analyses}

The assessment by ANOSIM indicated significant differences in the benthic community structure among the seasons (Global $R=0.417 ; p=0.009$ ). A seasonal analysis

Tab. 1. Physical and chemical variables at Bagliardi Beach, $\mathrm{n}=12$.

\begin{tabular}{lccc}
\hline & Mean \pm SD & Max & Min \\
\hline Temperature $\left({ }^{\circ} \mathrm{C}\right)$ & $20.08 \pm 5.38$ & $27.9(\mathrm{Dec})$ & $10.7(\mathrm{Jul})$ \\
Conductivity $\left(\mu \mathrm{S} \mathrm{cm}^{-1}\right)$ & $605 \pm 344$ & $1558(\mathrm{Sep})$ & $193(\mathrm{Nov})$ \\
Total dissol. solids $\left(\mathrm{mg} \mathrm{L}^{-1}\right)$ & $251 \pm 80.16$ & $339(\mathrm{Apr})$ & 203 (Aug) \\
Dissolved oxygen $\left(\mathrm{mg} \mathrm{L}^{-1}\right)$ & $5.49 \pm 1.85$ & $8.17(\mathrm{Jul})$ & $2.6(\mathrm{Jan})$ \\
Oxygen saturation $(\%)$ & $59.15 \pm 16.66$ & $79.6(\mathrm{Sep})$ & $32.1(\mathrm{Jan})$ \\
pH & $7.77 \pm 0.39$ & $8.67(\mathrm{Dec})$ & $7.36(\mathrm{Feb})$ \\
\hline
\end{tabular}


Tab 2. Benthic invertebrates on hard substrates at Bagliardi Beach. Frequency $(F r)$, dominance $(D)$, taxa richness $(S)$, total abundance per month $(N)$, equitability $\left(J^{\prime}\right)$, and Shannon-Wiener diversity index $\left(H^{\prime}\right)$; presence $(\mathrm{x})$.

\begin{tabular}{|c|c|c|c|c|c|c|c|c|c|c|c|c|c|}
\hline \multirow[b]{2}{*}{ Taxa } & \multicolumn{12}{|c|}{$D \%$} & \multirow[t]{2}{*}{$F r \%$} \\
\hline & Apr'01 & May’01 & Jun’01 & Jul'01 & Aug'01 & Sep’01 & Oct'01 & Nov'01 & Dec'01 & Jan'02 & Feb’02 & Mar'02 & \\
\hline \multicolumn{14}{|l|}{ ROTIFERA } \\
\hline Brachionus sp. & $\mathrm{x}$ & $\mathrm{x}$ & $\mathrm{x}$ & $\mathrm{x}$ & $\mathrm{x}$ & $\mathrm{x}$ & $\mathrm{x}$ & $\mathrm{x}$ & $\mathrm{x}$ & $\mathrm{x}$ & $\mathrm{x}$ & $\mathrm{x}$ & 100 \\
\hline $\begin{array}{l}\text { NEMATODA spp. } \\
\text { HIRUDINEA }\end{array}$ & 12.62 & 49.26 & 88.53 & 72.27 & 51.87 & 37.75 & 38.55 & 25.49 & 27.46 & 44.44 & 7.68 & 20.81 & 100 \\
\hline $\begin{array}{l}\text { Helobdella spp. } \\
\text { OLIGOCHAETA }\end{array}$ & 1.06 & 1.05 & 1.34 & 3.22 & 2.03 & 7.31 & 0.22 & 1.73 & 0.25 & 0.35 & 0.59 & 0.55 & 100 \\
\hline Tubificinae spp. & 2.9 & 6.42 & 0.96 & 6.95 & 12.88 & 4.07 & 2.44 & 0.99 & 0.91 & 2.18 & 4.26 & 0.81 & 100 \\
\hline $\begin{array}{l}\text { Naidinae spp. } \\
\text { GASTROPODA }\end{array}$ & 2.07 & 4.59 & - & 1.66 & 10.56 & 4.34 & - & - & 0.13 & - & 1.66 & 6.2 & 67 \\
\hline Uncanylus concentricus & - & - & 0.09 & 0.13 & 0.42 & 0.37 & 0.07 & 0.1 & - & - & - & 0.08 & 58 \\
\hline $\begin{array}{l}\text { Heleobia piscium } \\
\text { BIVALVIA }\end{array}$ & 3.12 & 0.63 & 0.32 & 0.18 & 0.25 & - & 0.15 & 9.58 & 1.25 & 1.18 & 0.72 & 0.3 & 92 \\
\hline $\begin{array}{l}\text { Limnoperna fortunei } \\
\text { TARDIGRADA }\end{array}$ & 76.98 & 32.59 & 7.89 & 12.99 & 13.27 & 28.88 & 48.01 & 59.54 & 67.5 & 45.3 & 82.09 & 67.36 & 100 \\
\hline $\begin{array}{l}\text { Dactylobiotus dispar } \\
\text { ACARI }\end{array}$ & - & 4.16 & 0.23 & 1.37 & 4.65 & 3.9 & 2.73 & 0.84 & 0.33 & 0.41 & 0.08 & 0.04 & 92 \\
\hline $\begin{array}{l}\text { Hydrachnidia spp. } \\
\text { COPEPODA }\end{array}$ & 0.95 & 0.67 & 0.47 & 0.71 & 1.44 & 0.73 & 4.8 & 0.49 & 0.17 & 0.12 & - & 0.04 & 92 \\
\hline Cletocamptus deitersi & - & - & 0.09 & 0.13 & 1.02 & - & - & 0.30 & 0.04 & 0.18 & 0.05 & 0.25 & 67 \\
\hline Cyclopidae & 0.11 & 0.26 & 0.06 & 0.04 & 0.34 & - & - & 0.05 & 0.13 & - & - & - & 58 \\
\hline $\begin{array}{l}\text { Centropagidae } \\
\text { CLADOCERA }\end{array}$ & 0.16 & & 0.03 & - & - & - & 0.15 & - & 0.04 & - & - & - & 33 \\
\hline Bosmina spp. & - & - & - & - & - & 0.12 & - & - & - & - & - & - & 8 \\
\hline Chydoridae spp. & - & 0.05 & - & 0.04 & 0.34 & - & - & 0.15 & - & - & - & - & 33 \\
\hline $\begin{array}{l}\text { Moina spp. } \\
\text { OSTRACODA }\end{array}$ & - & - & - & - & - & - & - & 0.2 & - & - & - & - & 8 \\
\hline $\begin{array}{l}\text { Cyprididae spp. } \\
\text { AMPHIPODA }\end{array}$ & - & 0.16 & - & - & - & - & - & 0.05 & - & - & - & 0.04 & 25 \\
\hline Corophium rioplatense & - & - & - & - & - & - & - & - & - & - & 0.03 & - & 8 \\
\hline $\begin{array}{l}\text { Hyalella curvispina } \\
\text { TANAIDACEA }\end{array}$ & - & - & - & - & - & 0.12 & - & - & 0.04 & 0.06 & - & - & 25 \\
\hline $\begin{array}{l}\text { Sinelobus standfordi } \\
\text { COLLEMBOLA }\end{array}$ & - & - & - & 0.04 & - & - & - & 0.2 & 1.58 & 5.6 & 2.73 & 3.29 & 50 \\
\hline Sminthuride ssp. & 0.05 & - & - & - & - & - & - & - & - & - & - & - & 8 \\
\hline $\begin{array}{l}\text { Ceratophysella } \text { sp. } \\
\text { EPHEMEROPTERA }\end{array}$ & - & - & - & - & - & 0.73 & 0.22 & - & - & - & - & - & 17 \\
\hline $\begin{array}{l}\text { Caenis spp. } \\
\text { DIPTERA }\end{array}$ & - & - & - & - & - & - & - & - & - & - & 0.03 & - & 8 \\
\hline Ceratopogonidae spp. & - & 0.05 & - & 0.04 & - & - & - & - & 0.04 & - & - & - & 25 \\
\hline Chironomidae spp. & - & 0.11 & - & 0.22 & 0.93 & 11.57 & 2.66 & 0.3 & 0.13 & 0.18 & 0.08 & 0.21 & 83 \\
\hline Dolichopodidae spp. & - & - & - & - & - & 0.12 & - & - & - & - & - & - & 8 \\
\hline Total & 100 & 100 & 100 & 100 & 100 & 100 & 100 & 100 & 100 & 100 & 100 & 100 & \\
\hline $\mathrm{N}\left(\right.$ ind $\left.\mathrm{m}^{-2}\right)$ & 432,858 & 433,878 & 785,383 & 517,763 & 270,125 & 187,679 & 309,521 & 462,687 & 548,494 & 387,794 & 853,795 & 541,395 & \\
\hline$S^{\prime}$ & 11 & 14 & 12 & 16 & 14 & 14 & 12 & 16 & 16 & 12 & 13 & 14 & \\
\hline$J^{\prime}$ & 0.38 & 0.51 & 0.2 & 0.37 & 0.61 & 0.65 & 0.5 & 0.42 & 0.32 & 0.46 & 0.3 & 0.39 & \\
\hline$H^{\prime}\left(\log _{2}\right)$ & 0.87 & 1.32 & 0.49 & 1.01 & 1.56 & 1.68 & 1.2 & 1.15 & 0.87 & 1.09 & 0.75 & 1.01 & \\
\hline
\end{tabular}

revealed that the faunal members associated hard substrates were the most similar during the autumn and spring $(R=0.074 ; p=0.3)$, as were those of the spring and summer ( $R=0.111 ; p=0.4)$, in contrast to those of the winter and spring $(R=0.889 ; p=0.1)$ and the winter and summer $(R=1$; $p=0.1)$.

These findings are clearly demonstrated by the nMDS analysis (Fig. 2), where the stress value was seen to be low $(S=0.1)$.
Relationship between biological and environmental variables

The results of Spearman's rank-correlation analysis are showed in Tab. 3. The temperature exhibited a significant negative correlation with the abundance of $U$. concentricus and a positive one with $L$. fortunei. The conductivity indicated a significant negative correlation with $C$. deitersi. The dissolved oxygen concentration and oxygen saturation evinced a significant negative correlation with Hydrachnidia 


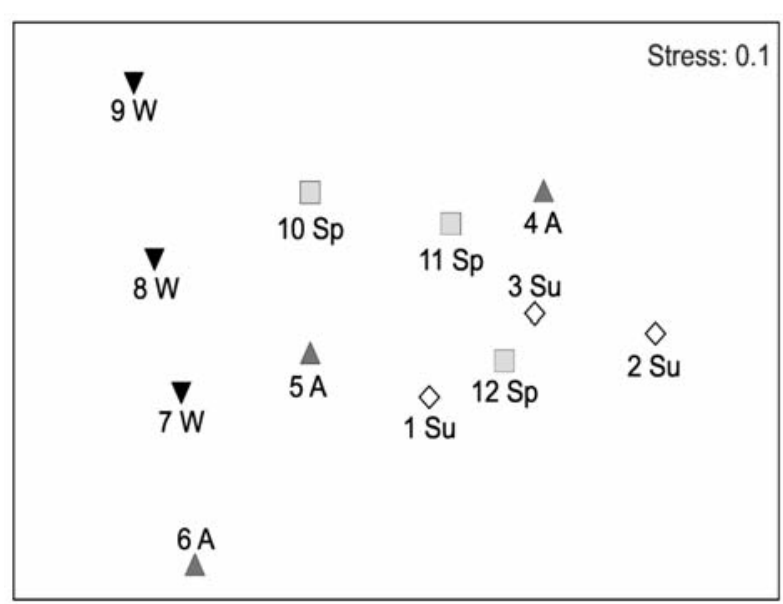

Fig. 2. Two-dimensional nMDS ordination plots of the benthic community on hard substrates during different seasons at Bagliardi Beach. Su (Summer), A (Autumn), W (Winter) and Sp (Spring); 1 (January), 2 (February), 3 (March), 4 (April), 5 (May), 6 (June), 7 (July), 8 (August), 9 (September), 10 (October), 11 (November), and 12 (December).

spp. The $\mathrm{pH}$ did not show any significant correlation with these hard-substrate fauna.

According to BIO-ENV analysis, T, Cond and DO were the best variables $(r=0.415)$ for explaining changes in the abundance over time of the hard-substrates benthic fauna under study (Tab. 4).

\section{FFGs}

The hard-substrate FFGs were dominated by the filtering and gathering collectors $(\mathrm{G} 2=50.4 \pm 25.1 \%)$. This group consisted in L. fortunei, Ciprideis sp., S. standfordi, Bosmina sp., Moina sp. Sminthurides sp., Ceratophysella sp., Caenis sp., and species of Chydoridae, Tubificinae, and Chironomidae. The deposit feeders and detritivores were sub-dominants FFGs ( $\mathrm{G} 1=44.2 \pm 24.7 \%)$. This group consisted in $\mathrm{H}$. curvispina, $D$. dispar, C. deitersi, and species of Cyclopidae, Centropagidae, Nematoda, and Naidinae. The next most abundant FFGs was the predators (G4 $=3.9 \pm 5.4 \%)$. This group did not account for more than $19.7 \%$ (September) and consisted in Helobdella spp., C. rioplatense, and species of Hydrachnidia, Ceratopogonidae, and Dolichopodidae. The least abundant FFGs was the scrapers $(\mathrm{G} 3=1.6 \pm 2.7 \%)$, which group included only H. piscium and U. concentricus (Fig. 3).

\section{DISCUSSION}

Structure and composition of benthic fauna on hard substrates

Before the invasion of $L$. fortunei in 1991 studies of benthic fauna on hard and soft substrates in the Río de la Plata Estuary were either scarce or absent altogether (Boschi 1988). This deficit makes a comparison of the current dynamics of benthic invertebrates with the one that existed before the introduction of the golden mussel difficult. Reports referred only to specific taxonomic groups. Darrigran, and Rioja (1988), for example, described fauna of the Isopoda, Gullo (1995) the diversity of the Hirudinea, and Darrigran (1999) the distribution of the Mollusca in the estuary. Furthermore, only few studies on benthic communities have been conducted on the Río de la Plata Estuary after the mussel's invasion, and those reports have dealt mostly with populations on soft substrates (Rodrigues Capítulo et al. 2003; Giberto et al. 2004; Cortelezzi et al. 2007; Ocón et al. 2008).

The benthic community on hard substrates at Bagliardi Beach was dominated by L. fortunei. This mollusk species is the principal component of the rocky shore fauna in Argentina as a result of its invasive characteristics: a high fecundity, a rapid growth, a short life span, a strong ability to disperse, and an effective occupation of vacant niches (Boltovskoy et al. 2006). The Nematoda was the second most dominant taxon. According to Rodrigues Capítulo et al. (1998) and Cortelezzi et al. (2007), the Nematoda and the Oligochaeta are the most frequent and abundant benthic organisms on soft substrates of this estuary, and mainly in

Tab. 3. Results of Spearman's correlation analysis between environmental variables and abundances of invertebrates on hard substrates. Only significant $(p<0.05)$ correlations are shown. Boldface characters highlight significant correlations with the Bonferroni test (Rice 1989). $T$ (temperature); Cond (conductivity); DO (dissolved oxygen); OS (oxygen saturation).

\begin{tabular}{|c|c|c|c|c|c|c|c|c|}
\hline & \multicolumn{2}{|c|}{$T$} & \multicolumn{2}{|c|}{ Cond } & \multicolumn{2}{|c|}{$D O$} & \multicolumn{2}{|c|}{$O S$} \\
\hline & $R$ & $p$ & $R$ & $p$ & $R$ & $p$ & $R$ & $p$ \\
\hline Helobdella spp. & -0.718 & 0.009 & & & & & & \\
\hline U. concentricus & -0.721 & 0.008 & & & 0.804 & 0.009 & & \\
\hline L. fortunei & 0.741 & 0.006 & & & -0.683 & 0.042 & & \\
\hline D. dispar & & & & & 0.75 & 0.02 & 0.683 & 0.042 \\
\hline Hydrachnidia spp. & & & & & 0.85 & 0.004 & 0.867 & 0.002 \\
\hline C. deitersi & & & -0.923 & 0.001 & & & & \\
\hline Cyclopidae & & & & & 0.693 & 0.038 & & \\
\hline S. standfordi & & & & & -0.797 & 0.01 & -0.712 & 0.031 \\
\hline Ceratophysella sp. & & & 0.65 & 0.022 & & & & \\
\hline Dolichopodidae spp. & & & & & 0.695 & 0.038 & & \\
\hline
\end{tabular}


Tab. 4. Summary of the 10 best combinations obtained from BIO-ENV analysis for various sets of Spearman's correlations between environmental vari-ables and abundances of taxa.

\begin{tabular}{lcc}
\hline Number of variables & $r$ value & Variables implicated \\
\hline 3 & 0.415 & $T^{o}$, Cond, $D O$ \\
4 & 0.407 & $T^{o}$, Cond, OS, DO \\
5 & 0.399 & $p H, T^{o}$, Cond, OS, DO \\
4 & 0.399 & $p H, T^{o}$, Cond, $D O$ \\
2 & 0.380 & $T^{o}, D O$ \\
2 & 0.379 & $T^{o}, O S$ \\
4 & 0.378 & $p H, T^{o}$, Cond, OS \\
3 & 0.376 & $T^{o}$, Cond, OS \\
3 & 0.358 & $p H, T^{o}, D O$ \\
3 & 0.355 & $p H, T^{o}, O S$ \\
\hline
\end{tabular}

zones with high organic matter in the sediments. The Nematoda is highly resistant to desiccation, low dissolved-oxygen concentrations, and a broad range of temperature (Ocón et al. 2008; Adão 2009). In previous studies of benthic fauna on hard substrates (Darrigran et al. 1998) the Nematoda was not taken into account in the analysis, but in our samples we did consider the Nematoda along with $L$. fortunei as being the central faunal groups because of their constant dominance within the community assemblage. The Oligochaeta and the Hirudinea were the next principal groups that appeared during every month. Before the introduction of $L$. fortunei at Bagliardi Beach, Gullo, and Darrigran (1991) had described two species of Hirudinea and three species of Oligochaeta at this site. After the settlement of the golden mussel, Darrigran et al. (1998) reported eight species of Hirudinea and eight species of Oligochaeta there. According to those authors, Helobdella spp. was the dominant group of Hirudinea, while the Tubificinae and the Naidinae were the principal groups of the Oligochaeta. After the invasion of L. fortunei, the indigenous species of Gastropoda, Chilina fluminea Maton and Biomphalaria straminea Dunker became rare and with very infrequent dominance (Darrigran et al. 1998). Neither of these species appeared in our samples, however, and may thus have been displaced from the community. The gastropoda, U. concentricus and H. piscium were common, but at a very low abundance, in contrast to the high dominance and frequency previously found in Darrigran et al. (1998). Other benthic invertebrates (e.g., Cladocera, Ostracoda and Collembola) were irregularly distributed at a low abundance and frequency. We therefore considered these taxa as occasional. Among the taxa that we found, the following had not been reported before on hard substrates in the Río de la Plata Estuary: Rotifera, Tardigrada, Hydrachnidia, Cladocera, Ostracoda, Harpacticoidea, Calanoidea, Cyclopoidea, Collembola, Ephemeroptera, Ceratopogonidae, and Dolichopodidae. The differences between the present findings and previous results could well be explained by the fine-meshed sieves used by us, or alternatively, through the occurrence of new groups associated with that hard substrate over time. In the lower delta of the Paraná, a large floodplain river that flows into the Río de la Plata Estuary, Sylvester et al. (2007b) evaluated the effect of $L$. fortunei on the abundance and biomass of the benthic invertebrates present. Those authors used artificial substrates surrounded by cages so that predators (such as fish) were excluded from the experiment. The dominant invertebrates - the Oligochaeta, Nematoda, Rotifera, Copepoda, Gastropoda, Hirudinea, and Chironomidae - were numerous, and their abundance was positively correlated with the mussels' biomass.

In a study conducted in the Río de la Plata Estuary during the spring of 2001, Cortelezzi et al. (2007) reported that the lowest density of benthic invertebrates on soft substrates $\left(N=1500\right.$ ind. $\left.\mathrm{m}^{-2}\right)$ occurred in the middle zone of the estu-

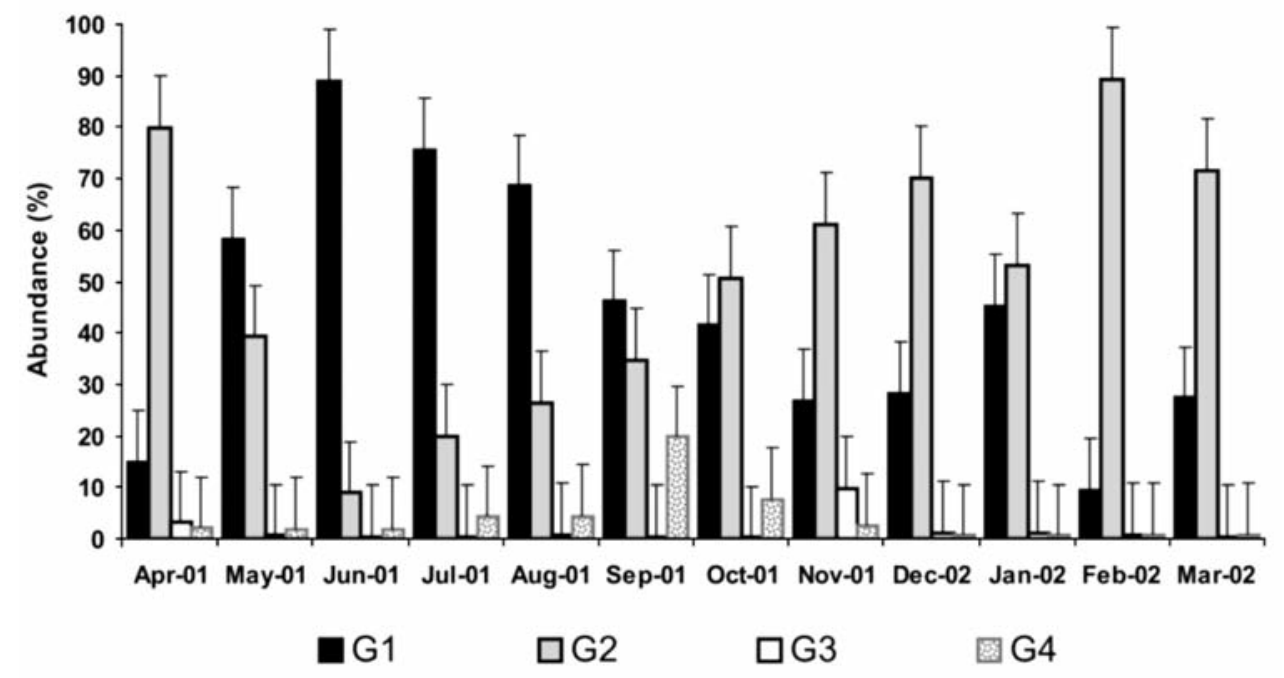

Fig. 3. Functional Feeding Groups in percent abundance (\%): G1 (deposit feeders and detritivores), G2 (filterers and gathering collectors), G3 (scrapers) and G4 (predators). 
ary, while the highest density $\left(\mathrm{N}>10,000\right.$ ind $\left.\mathrm{m}^{-2}\right)$ was located in the inner and lower zones (near the oceanic front). In our work, the density on hard substrates in the spring was $440,232 \pm 121,058$ ind $\mathrm{m}^{-2}$. Ocón et al. (2008) carried out a seasonal study of benthic invertebrates in the middle zone of the Río de la Plata Estuary along $80 \mathrm{~km}$ of coast lying to the south of Bagliardi Beach, at open beaches and in the mouths of the streams there that discharge into the estuary. In all of the eighteen sampling sites those investigators recorded a total richness of 49 taxa on soft substrates. In our study, a total of 26 taxa were registered on the hard substrate of only a single sampling site. According to Cortelezzi et al. (2007), the diversity in the Río de la Plata Estuary was between 0.18 and 2.36, with the value in the middle zone being $H^{\prime}=1.71 \pm 0.41$; while Ocón et al. (2008) found that the diversity varied between 0.95 and 1.99 for that same zone of the estuary. At Bagliardi Beach we registered similar diversity value (between 0.49 and 1.68 , with $H^{\prime}$ expressed as $\log _{2}$ ).

In general, the highest diversity, taxa richness, and evenness were recorded at Bagliardi Beach in the winter, while the highest abundance of individuals was registered in the summer. The ANOSIM and nMDS diagram indicated that the benthic structure and composition exhibited a seasonal variation within the study area. The diversity, density, and taxa richness on that hard substrate were slightly variable throughout the year sampled, but the dominance of taxa such as L. fortunei, Nematoda and Oligochaeta - was clear and constant. This constancy may be reflecting the community stability, even when exposed to any significant disturbance of the estuary. The presence of certain taxa - mainly the opportunistic and the occasional fauna - may be attributed to the flow dynamics of the estuary down from the upper (freshwater) zone and to drifting. For example, the Paraná and Uruguay rivers discharge into the Río de la Plata Estuary from about $15,000 \mathrm{~m}^{3} \mathrm{~s}^{-1}$ of water in the dry season to some $26,000 \mathrm{~m}^{3} \mathrm{~s}^{-1}$ during the wet season. The flow thus rises sharply in May, peaking between July and September, but then drops down to minimum values in December and January. In the spring through the summer the freshwater discharge is the lowest, the northeast winds become predominant, and a buoyant strip of water extends along the Argentine coast, while the freshwater discharge has its peak in the autumn and winter (Guerrero et al. 1997).

\section{Environmental conditions and biological variables}

A few benthic invertebrates on these hard substrates were found to be highly correlated with specific physicochemical variables: For example, U. concentricus was relatively sensitive to environmental changes and required a high dissolved-oxygen concentration (Rodrigues Capítulo et al. 2001); whereas, with temperature being the main variable controlling the spawning of the golden mussel in temperate environments, the abundance of $L$. fortunei proved to be highly temperature-related. Accordingly, two strong spawning events occur within a given year at Bagliardi Beach, first during the spring and then during the summer, each with a high abundance of recruits $(<1 \mathrm{~mm}$; Darrigran et al. 2003; Spaccesi, unpublished data). The correlation between all the environmental variables and the biotic patterns, as observed in the BIO-ENV analysis, indicated that temperature and conductivity were the best factors to explain the benthic composition on the whole. Although physical and chemical conditions are decisive for the settlement and development of several aquatic invertebrates, the occurrence and abundance of benthic organism is perhaps more closely related to the resources and the functional dynamics offered by $L$. fortunei. The golden mussel was the sole sessile organism (with a stationary life as the adult) on the three-dimensions of the granite rocks (i.e., hard substrates) at Bagliardi Beach. The mean size of those individuals was between 8 to $12.7 \mathrm{~mm}$ (Spaccesi, unpublished data); but because the others benthic invertebrates were much smaller $(<1 \mathrm{~mm})$ and were moreover vagile, they colonized the cracks and cavities between the $L$. fortunei shells. The physical irregularity of the mussel's surface decreased the influence of wave action, temperature and sunlight; while increasing the relative humidity and sedimentation in that new microhabitat. The amount of available space to serve as a microhabitat for benthic organisms is proportional to that surface's complexity, which additional potential colonization space with this mussel accommodated an increasing number of species of smaller animals and enhanced the recruitment of aquatic species (Kostylev et al. 2005). We agree with Karatayev et al. (2007) and Sylvester et al. (2007b) that in such a circumstance L. fortunei acts as an ecological engineer to benefit many other benthic invertebrates by providing additional resources through an increase in the complexity of the available microhabitat and the heterogeneity of hard substrates for possible colonization.

\section{Associated invertebrates and FFGs}

The hard-substrate communities at Bagliardi Beach contained a high abundance of filterers, gathering collectors, deposit-feeders, and detritivores. The major food source for these FFGs was organic matter in the form of phytoplankton or residual material (e.g., feces, pseudofeces, bacteria, and detritus) generated by $L$. fortunei excretion, zooplankton grazing, decomposition, and other processes in the water column. The filterers, gathering collectors, deposit-feeders, and detritivores are sustained by high depositions of organic carbon (Sylvester et al. 2005, 2007a; Sardiña et al. 2008). Other FFGs such as the scrapers (U. concentricus) graze the microalgae (César et al. 2000) that cover the golden mussel's shells. The high turbidity of the Río de la Plata Estuary, moreover, probably determines the number of species capable of surviving in such estuarine waters, but also provides a high level of suspended particulate matter that may explain 
the dominant FFGs described here. Finally, the deposit-feeders or detritivores - such as the Nematoda - for their part, constitute an abundant food source for another FFG namely, the predators, such as the Hirudinea.

\section{CONCLUSIONS}

The lack of research of benthic fauna with habitats on hard substrates in the Río de la Plata Estuary makes the formulation a general prediction difficult and has generated several speculations on the real effect of $L$. fortunei on the native fauna of South America. Nevertheless, comparison between L. fortunei and Dreissena polymorpha Pallas (the zebra mussel), an invasive pest in the biota of North America and Europe is valid. Both species have similar ecological characteristics. After the zebra mussels invaded several lentic and lotic ecosystems in the Northern Hemisphere, the benthic-invertebrate communities there changed significantly in terms of total biomass, species composition, and relative abundance of FFGs (Karatayev et al. 2007). That mussel increased the abundance and diversity of certain benthic invertebrates - e.g., species of Hydrozoa, Turbellaria, Hirudinea, Tubificidae, Gastropoda, Amphipoda, Decapoda, Trichoptera, and Chironomidae (Stewart, and Haynes 1994; Horvath et al. 1999; Karatayev et al. 2007), but in many other instances reduced or eliminated specific taxa - e.g., species of Unionidae, Polycentropodidae, Hydropsychidae, Pleuroceridae, and Plumatellidae (Nalepa 1994; Ricciardi et al. 1997; Lozano et al. 2001; Strayer 2009). In Eastern Europe, native filter feeders were outcompeted by $D$. polymorpha and decreased in abundance, but that FFG was found able to coexist with the mussels even though the zebra mussel did cause a dramatic decline in the density of the Unionidae (Karatayev et al. 1997).

\section{ACKNOWLEDGMENTS}

This work has been funded by a grant from Comisión de Investigaciones Científicas de la Provincia de Buenos Aires (CIC), and PICT 32077 (ANPCyT and UNLP), Argentina. We thank the anonymous reviewers for their suggestion and critical comments for improving this manuscript. Special thanks to Dr Aldo Spaccesi for his valuable technical assistance in field. We are indebted to Joanne Marciano for kindly helping with the English translation of this manuscript and to Dr Donald F. Haggerty, a retired career investigator and native English speaker, for editing the final draft. Scientific contribution $\mathrm{n}^{\circ} 912$ of Institute of Limnology "Dr. Raúl Ringuelet", ILPLA.

\section{REFERENCES}

Adão H, Alves AS, Patrício J, Magalhães Neto J, Costa MJ, and Marques JC. 2009. Spatial distribution of subtidal Nematoda communities along the salinity gradient in southern European estuaries. Acta Oecol. 35: 287-300.
Attrill M, and Rundle S. 2002. Ecotone or ecocline: ecological boundaries in estuaries. Estuar. Coast. Shelf. Sci. 55: 929-936.

Atrill M, Ramsay P, Thomas Myles R, and Trett M. 1996. An estuarine biodiversity hot-spot. J. Mar. Biol. Assoc. U.K. 76: 161-175.

Bazán JM, and Arraga E. 1993. El Río de la Plata ¿un sistema fluvio-marítimo frágil? Acercamiento a una definición de la calidad de sus aguas. In: A. Boltovskoy, and H.L. Lopéz (Eds), Conferencia de Limnología. Instituto de Limnología "Dr R.A. Ringuelet”, La Plata, Argentina: 71-82 (en español).

Boltovskoy D, Correa N, Cataldo D, and Sylvester F. 2006. Dispersion and ecological impact of the invasive fresh-water bivalve Limnoperna fortunei in the Río de la Plata watershed and beyond. Biol. Invasions 8: 947-963.

Bonetto AA, and Wais IR. 1995. Southern South American streams and rivers. In: Cushing, C.E., K.W. Cummins, and G.W. Minshall (Eds), Ecosystems of the World 22, River and stream ecosystems, Amsterdam, The Netherlands, Elsevier: 257-293.

Boschi E. 1988. El ecosistema estuarial del Río de la Plata (Argentina y Uruguay). Anales del Inst. Cs. del Mar y Limnol. UNAM, 15: 159-182 (en español).

César I, Ocón C, Paggi A, Rodrigues Capítulo A, Spaccesi F, Tangorra M, and Tassara M. 2000. Diversidad de invertebrados bentónicos del Río de la Plata. Biología Acuática, 19: 37-63 (en español).

Clarke KR, and Warwick RM. 2001. Change in Marine Communities: An Approach to Statistical Analysis and Interpretations. 2nd ed., PRIMER-E, Plymouth, UK: 172 pp.

Cortelezzi A, Rodrigues Capítulo A, Boccardi L, and Arocena R. 2007. Benthic assemblages of a temperate estuarine system in South America: Transition from a freshwater to an estuarine zone. J. Marine Syst. 68: 569-580.

Cummins KW, and Klug. 1979 MJ. Feeding ecology of stream invertebrates. Annu. Rev. Ecol. Evol. S. 10: 147-172.

Cummins KW, and Wilzbach MA. 1985. Field procedures for analysis of functional feeding groups of streams macroinvertebrates. Pymatuning Lab. Ecol., Univ. Pittsburgh, Linesville, PA: $18 \mathrm{pp}$.

Darrigran G, and Pastorino G. 1995. The Recent Introduction of a Freshwater Asiatic Bivalve, Limnoperna fortunei (Mytilidae) into South America. Veliger 38: 171-175.

Darrigran GA. 1999. Longitudinal distribution of molluscan communities in the Río de la Plata estuary as indicators of environmental conditions. Malacol. Rev. supl. Freshwater Mollusca 8:1-12.

Darrigran GA, and Rioja S. 1988. Distribución y selección de ambientes de los isópodos talasoides del Río de la Plata, República Argentina. Neotropica, 36:105-114 (en español).

Darrigran G, Damborenea MC, Penchaszadeh P, and Taraborelli C. 2003. Adjustments of Limnoperna fortunei (Bivalvia: Mytilidae) after ten years of invasion in the Americas. J. Shellfish Res. 22: 141-146.

Darrigran G, Martin SM, Gullo B, and Armendáriz L. 1998. Macroinvertebrates associated with Limnoperna fortunei (Dunker, 1857) (Bivalvia, Mytilidae) in Río de la Plata, Argentina. Hydrobiologia, 367: 223-230.

Day Jr JW, Hall CAS, Kemp WM, and Yañez-Arancibia A. 1989. Estuarine Ecology. J. Wiley, and Sons, New York: 558 pp.

Fernández HR, and Domínguez E. 2001. Guía para la determinación de artrópodos bentónicos sudamericano. Editorial Universitaria de Tucumán, Argentina: 282 pp (en español).

Giberto DA, Bremec CS, Acha EM, and Mianzan H. 2004. Largescale spatial patterns of benthic assemblages in the SW At- 
lantic: the Río de la Plata estuary and adjacent shelf waters. Estuar. Coast. Shelf. S. 61: 1-13.

Giménez L, Borthagaray AI, Rodríguez M, Brazeiro A, and Dimitriadis C. 2005. Scale-dependent patterns of macro-faunal distribution in soft-sediment intertidal habitats along a large-scale estuarine gradient. Helgol. Mar. Res. 59: 224-236.

Guerrero RA, Acha EM, Framiña MB, and Lasta CA. 1997. Physical oceanography of the Río de la Plata estuary, Argentina. Cont. Shelf. Res. 17: 727-742.

Gullo BS. 1995. Composición de la hirudofauna asociada al biso de Limnoperna fortunei (Dunker, 1857) (Pelecipoda, Mytlidae) en el Balneario Bagliardi, Río de la Plata, República Argentina. Resúmenes XVII Reunión Argentina de Ecología. Mar del Plata (en español).

Gullo BS, and Darrigran GA. 1991. Distribución de la fauna de hirudíneos litorales del estuario del Río de la Plata, República Argentina. Biología Acuática. Notas Científicas II Reunión Argentina de Limnología, La Plata, 15: 216-217 (en espanol).

Horvath TG, Martin KM, and Lamberti GA. 1999. Effect of Zebra Mussels, Dreissena polymorpha, on Macroinverte-brates in a Lake-outlet Stream. Am. Mid. Nat. 142: 340-347.

Karatayev AY, Burlakova LE, and Padilla DK. 1997. The effects of Dreissena polymorpha (Pallas) invasion on aquatic communities in Eastern Europe. J. Shellfish Res. 16: 187-203.

Karatayev AY, Boltovskoy D, Padilla DK, and Burlakova LE. 2007. The invasive bivalves Dreissena polymorpha and Limnoperna fortunei: parallels, contrasts, potential spread and invasion impacts. J. Shellfish Res. 26: 205-213.

Kiddon JA, Paul JF, Buffum HW, Strobel CS, Hale SS, Cobb D, and Brown BS. 2003. Ecological condition of US Mid-Atlantic estuaries, 1997-1998. Mar. Pollut. Bull. 46: 1224-1244.

Kostylev VE, Erlandsson J, Yiu Ming M, and Williams GA. 2005. The relative importance of habitat complexity and surface area in assessing biodiversity: fractal application on rocky shores. Ecol. Complex. 2: 272-286.

Licursi M, Gómez N, and Donadelli J. 2010. Ecological optima and tolerances of coastal benthic diatoms in the freshwatermixohaline zone of the Río de la Plata estuary. Mar. Ecol. Prog. Ser. 418: 105-117.

Lozano SJ, Scharold JV, and Nalepa TF. 2001. Recent declines in benthic macroinvertebrate densities in Lake Ontario. Can. J. Fish. Aquat. Sci. 58: 518-529.

Lopretto EC, and Tell G. 1995. Ecosistemas de aguas continentales. Metodología para su estudio. Ediciones Sur, Argentina, Tomo II and Tomo III: 895 pp (en español).

Mateucci SD, and Colma A. 1982. Metodología para el estudio de la vegetación. Secretaría General de la OEA, Programa Nacional de Desarrollo Científico y Tecnológico, Washington DC, Monografía científica $\mathrm{N}^{\circ}$ 22: 168 pp (en español).

McLusky DS, and Elliott M. 2004. The Estuarine Ecosystem: ecology, threats and management. New York: Oxford University Press Inc. 3rd ed.: 224 pp.

Merritt RW, and Cummins KW. 1996. An introduction to the aquatic insects of North America. 3rd ed. Iowa: Kendall/Hunt Publishing Company: 862 pp.

Mianzan H, Lasta C, Acha E, Guerrero R, Macchi G, and Bremec C. 2001. The Rio de la Plata Estuary, Argentina-Uruguay. In: Seeliger U, and Kjerfve B (Eds), Coastal Marine Ecosystems of Latin America. Ecological Studies, Springer Verlag, Berlin. 144: $185-204$.

Moreno CE. 2001. Métodos para medir la biodiversidad. Manuales y Tesis SEA, Zaragoza, España: 84 pp (en español).

Nalepa TF. 1994. Decline of native unionid bivalves in Lake St.
Clair after infestation by the zebra mussel, Dreissena polymorpha. Can. J. Fish. Aquat. Sci. 51: 2227-2233.

Ocón C, Rodrigues Capítulo A, and Paggi A. 2008. Evaluation of zoobenthic assemblages and recovery following petroleum spill in a coastal area of Río de la Plata estuarine system, South America. Environ. Pollut. 156: 82-89.

Rice WR. 1989. Analyzing tables of statistical tests. Evolution 43: 223-225.

Ricciardi A, Whoriskey FG, and Rasmussen JB. 1997. The role of the zebra mussel (Dreissena polymorpha) in structuring macroinvertebrates communities on hard substrata. Can. J. Fish. Aquat. Sci. 54: 2596-2608.

Rodrigues Capítulo A, Tangorra M, and Ocón C. 2001. Use of benthic macroinvertebrates to assess the biological status of Pampean streams in Argentina. Aquat. Ecol. 35: 109-119.

Rodrigues Capítulo A, César I, Tassara M, Paggi AC, and Remes Lenicov M. 1998. Distribution of the macrobenthic fauna of the South Coastal Fringe of the Rio de la Plata river (Argentine). Impact of the urban contamination. Verh. Internat. Verein. Limnol. 26: 1260-1265.

Rodrigues Capítulo A, Ocón C, Tangorra M, Paggi AC, Cortelezzi A, and Spaccesi FG. 2003. Estudios zoobentónicos recientes en el Río de la Plata. Biología Acuática 21: 18-29 (en español).

Sardiña P, Cataldo DH, and Boltovskoy D. 2008. The effects of the invasive mussel, Limnoperna fortunei, on associated fauna in South American freshwaters: importance of physical structure and food supply. Fundam. Appl. Limnol. 173: 135-144.

SHN (Servicio de Hidrografía Naval). 2001. Tablas de marea: Puertos de la República Argentina y algunos puertos de Brasil, Uruguay y Chile. Servicio de Hidrografía Naval (Ed.), Armada Argentina, República Argentina: 504 pp (en español).

StatSoft Inc. 2001. Statistica for Windows v.6.0. Data analysis software system, Tulsa, Oklahoma, USA.

Stephenson TA, and Stephenson A. 1949. The universal features of zonation between tidemarks on rocky coasts. J. Ecol. 37: 289-305.

Stewart TW, and Haynes JM. 1994. Benthic Macroinvertebrate Communities of Southwestern Lake Ontario Following Invasion of Dreissena. J. Great Lakes Res. 20: 497-493.

Strayer DL. 2009. Twenty years of zebra mussels: lessons from the mollusk that made headlines. Front. Ecol. Environ. 7: 135141.

Sylvester F, Boltovskoy D, and Cataldo DH. 2007a. Fast response of freshwater consumers to a new trophic resource: Predation on the recently introduced Asian bivalve Limnoperna fortunei in the lower Paraná River, South America. Austral Ecol. 32: 403-415.

Sylvester F, Boltovskoy D, and Cataldo DH. 2007b. The invasive bivalve Limnoperna fortunei enhances benthic invertebrate densities in South American flood plain rivers. Hydrobiologia 589: $15-27$.

Sylvester F, Dorado J, Boltovskoy D, Juárez A, and Cataldo DH. 2005. Filtration rates of the invasive pest bivalve Limnoperna fortunei as a function of size and temperature. Hydrobiologia 534: 71-80.

Venturini N, Muniz P, and Rodríguez M. 2004. Macrobenthic subtidal communities in relation to sediment pollution: the phylum-level meta-analysis approach in a south-eastern coastal region of South America. Mar. Biol. 144: 119-126.

Wells PG, and Daborn GR. 1997. The Río de la Plata. An environmental overview. An EcoPlata project background report, Dalhousie University, Halifax, Nova Scotia, Canada: 248 pp. 